\title{
Antibacterial Properties of Bambusa vulgaris (Bamboo) Leaves and Eryngium foetidum (Culantro) Leaves against Staphylococcus aureus and Escherichia coli bacteria
}

\author{
Marloie T. Menchavez*, Jerico D. Catipay, Aileen S. Espra, Pedrito M. Castillo II \\ 1 Senior High School Department, University of Mindanao, Bolton St, Talomo, Davao City, 8021 Davao del Sur, Philippines \\ 2Department of Science and Technology, Caraga State University, Ampayon Campus National Highway, NH1, Butuan City, 8600 Agusan Del Norte, Philippines
}

Correspondence Author: Marloie T. Menchavez*. Senior High School Department, University of Mindanao, Bolton St, Talomo, Davao City, 8021 Davao del Sur, Philippines.

E-mail: marloiemenchavez@gmail.com

Received date: 22 January 2018, Accepted date: 22 June 2018, Online date: 8 August 2018

Copyright: () 2018 Menchavez et al. This is an open-access article distributed under the terms of the Creative Commons Attribution License, which permits unrestricted use, distribution, and reproduction in any medium, provided the original author and source are credited.

\begin{abstract}
Staphylococcus aureus and Escherichia coli are considered to be two of the most prevalent gram-positive and gram-negative bacteria, and the most frequent sources of bacterial infections and hospital-acquired diseases worldwide (Bachir raho and Abouni, 2015). This investigation examines the antibacterial properties of Bambusa vulgaris (Bamboo) leaves and Eryngium foetidum (Culantro) leaves against the microbial growth of $S$. aureus and E. coli in vitro, and determines the phytochemical constituents present in the ethanol extracts that could be responsible for the said mechanism of action. Phytochemical Analysis and Antibacterial Test - Paper Disc Diffusion Method were the standardized laboratory methods used in the study. Based on the result of phytochemical screening, the identified phytochemicals present in Bambusa vulgaris ethanol extract were alkaloids, quaternary bases, amines, unsaturated steroids, and saponins. On the other hand, Eryngium foetidum ethanol extract contains alkaloids, quaternary bases, amines, 2 deoxysugars, unsaturated steroids, and tannins. The antibacterial activity of B. vulgaris and E. foetidum extracts were evaluated using Staphylococcus aureus (gram-positive) and Escherichia coli (gram-negative). Zone of inhibition was observed in vitro via paper disc diffusion method. $B$. vulgaris reached $26 \mathrm{~mm}$ on the first trial, $27 \mathrm{~mm}$ on the second and $26 \mathrm{~mm}$ on the third trial with an average of $26 \mathrm{~mm}$ against $S$. aureus, whereas in inhibiting the growth of $E$. coli bacteria, it reached $20 \mathrm{~mm}$ growth inhibition from trials 1 to 3 respectively. The extract from the E. foetidum (culantro) leaves grasped $22 \mathrm{~mm}$ on the first trial and $23 \mathrm{~mm}$ on the second and third trial with an average of $23 \mathrm{~mm}$ against $S$. aureus, while in E. coli it exhibited $20 \mathrm{~mm}$ of zone inhibition from first to second trial and $21 \mathrm{~mm}$ on the third trial with an average of $20 \mathrm{~mm}$. The results of the tests on both samples implicate that these plants could potentially be used as antibacterial agents and on other medicinal applications. These findings could provide a prognostic approach in terms of addressing the manifestations caused by the foregoing detriments.
\end{abstract}

Key words: Phytochemical Analysis, Bambusa vulgaris, Eryngium foetidum, Staphylococcus aureus, Escherichia coli, Antibacterial Test, Paper Disc Diffusion Method

\section{INTRODUCTION}

Throughout the years, the number of cases associated with bacterial infections and hospital-acquired diseases have been catastrophic. In fact, infectious diseases are included in the leading causes of mortality in the world (World Health Organization, 2017) and still increasing significantly. While health care has been one of the top priorities for governments worldwide, infectious diseases still remain a major public health concern (Smith et al., 2016).

Henceforth, Staphylococcus aureus (S. aureus) and Escherichia coli (E. coli) are considered to be the most frequent sources of fatal infections and hospital-acquired diseases (Bachir raho and Abouni, 2015). Staphylococcus aureus is a grampositive coccus that induce multitudinous suppurative (pus - forming) infections and superficial skin lesions such as boils, styes and furuncles; serious infections include pneumonia, meningitis, phlebitis, mastitis, and urinary tract infections; and entrenched infections including osteomyelitis and endocarditis. The pathogen could instigate food poisoning by releasing enterotoxins into food, and superantigen-release in the blood stream causing toxic shock syndrome. Also, Escherichia coli is a gram-negative bacillus that is commonly found in the digestive tract of humans and warm-blooded animals. While most strains of E. coli are harmless, some types can cause several infections and illnesses such as Enterotoxigenic E. coli (ETEC) that is the major cause of traveler's diarrhea and other bacterial diarrheal illness; and Shiga toxin-producing E. coli (STEC), known as E. coli O157:H7 that induces toxins causing severe foodborne disease and intestinal infection (World Health Organization, 2018; Madappa, 2017). 
Citation: Marloie T. Menchavez., Jerico D. Catipay., Aileen S. Espra., Pedrito M. Castillo., 2018. Antibacterial Properties of Bambusa vulgaris (Bamboo) Leaves and Eryngium foetidum (Culantro) Leaves against Staphylococcus aureus and Escherichia coli bacteria. Journal of Medicinal Plant Research., 6(1): 6-13. DOI: 10.22587/gjmpr.2018.6.1.2

Anent to this, infectious diseases were estimated to have caused 4.6 million deaths worldwide in 2015 alone (World Health Organization, 2017). In the Philippines, infectious diseases are included in the leading causes of death in all regions (Philippine Statistics Authority, 2016; Department of Health, 2013).

The development of antibiotics had made a significant contribution to the global health community for decades, reducing the incidence and prevalence of infectious diseases worldwide. However, the emergence of several multidrug-resistant pathogens due to mutation (Klevens et al., 2007) has threatened the efficacy of these treatments (Bandow et al., 2003) and became a global public health threat (Hogberg et al., 2010). Furthermore, the prognosis of the current problem is predicted to worsen, given that there is a decline in the development of new antibiotic drugs, and the cases of bacterial infections are increasing. Ergo, there is an urgent need to formulate new strategies to combat the proliferating cases of infectious diseases; one of which is to cogitate the screening of medicinal herbs and plants for their antimicrobial properties.

Phytochemicals, which occur naturally in plants such as alkaloids, flavonoids, saponins, and tannins have generated particular interest with regard to human health effects, specifically antibacterial activity (Aniszewski, 2007; Cushnie and Lamb, 2005; Scalbert, 2001; Arabski et al., 2011). Published literatures indicated that the aforementioned phytochemicals are functional constituents present in several species of bamboo (Kaur et al., 2015; Durgesh and Tumane, 2014) and culantro (Okon et al., 2013).

Bambusa vulgaris or common bamboo is a fast growing and giant tropical clumping bamboo that could grow up to 10 $20 \mathrm{~m}$ in height and $4-10 \mathrm{~cm}$ in diameter. It is native to China and Madagascar, but is widely cultivated in many parts of the world. The chloroform extract of its leaves is used to treat Mycobacterium tuberculosis, and tabasheer obtained from the culm internodes is used for several medicinal applications, such as treating kidney troubles, bark anstringent, emmenagogue, infantile epilepsy, fever and hematuria (Schröder, 2011). The effective ingredients of bamboo leaf include flavones, phenolic acid, lactones, amino acids and micronutrients (Sahbuti, 2004). Worldwide, bamboo has made a mark in the field of functional and medical health food with its rich antioxidant resource and specific functional factors (Goyal et al., 2010).

On the same vein, Eryngium foetidum or Culantro is a biennial herb native to continental tropical America and the West Indies. It is commonly found in moist areas where heavy soils preponderate. It is also widely used in dishes throughout the Caribbean, Latin America, and the Far East as a food flavoring and seasoning herb for a wide variety of foods. Culantro is purportedly abundant in iron, carotene, calcium, and riboflavin. The plant is also used in a broad spectrum of medicinal applications such as, treating fevers, chills, vomiting, diarrhea, pneumonia, flu, diabetes, constipation, colds, stomach pains, and malaria fever (Honeychurch, 1980; Mahabir 1991; Ramcharan, 1999). The decoction from its leaves was also found to exhibit anti-inflammatory properties (Sáenz et al., 1997).

Though several published studies have examined the antibacterial properties and phytochemical constituents of Bambusa vulgaris and Eryngium foetidum, the data reports are still limited, specifically in the Philippines. Also, given the fact that these plants are abundant in numbers; have been shown to exhibit antibacterial properties; and are cultivated in many parts of the world, these could be used as an alternative treatment for numerous diseases and infections caused by $S$. aureus and E. coli bacteria. Accordingly, the primary goal of this study is to evaluate the antibacterial activity of Bambusa vulgaris and Eryngium foetidum in inhibiting the growth of the aforementioned strains of bacteria in vitro using the synthesized ethanol extracts from both plants' leaves, distinctly. Investigating this area could provide a novel perspective in the global health industry in terms of addressing the manifestations caused by the foregoing detriments. This study would also contribute to the body of knowledge, primarily in instituting scientific bases to consider the use medicinal plants and herbs in developing and formulating therapeutic drugs to treat numerous diseases and derangements.

Phytochemical Analysis

\section{METHODS}

Preparation and Extraction of the Plant Sample for Phytochemical Analysis

One kilogram of each plant sample was collected. The leaves were air dried for about one week to let the dews evaporate, then cut and shredded into smaller pieces. The method is based from A Guidebook to Plant Screening: Phytochemical and Biological Screening (Guevara, 2005). The method was used to do the phytochemical screening of the plant extract. One kilogram dried ground plant is weighed in an Erlenmeyer flask. The sample was then treated with $80 \%$ ethyl alcohol to completely submerge the sample. The stopper of flask was then placed and the material was soaked for 24-48 hours. The extract was filtered through Buchner funnel with gentle suction. The flask and plant material was rinsed with fresh portion of alcohol. The washings and plant material was transferred to the funnel, combined with the washings of the first filtrate. It was then applied with gentle suction to complete collection of the plant extract. The plant residue was discarded. The filtrate was concentrated under vacuum at temperature below $50^{\circ} \mathrm{C}$ to about $20 \mathrm{~mL}$. The extract was then measured. The extracts of the plants were then stored in cold place at $0^{\circ} \mathrm{C}$ to $-5^{\circ} \mathrm{C}$ temperature.

Phytochemical Screening for Alkaloids

a. Preparation of Reagents

1. Mayer's Reagent - 1.4 grams of Mercuric iodide $\left(\mathrm{HgI}_{2}\right)$ is dissolved in $60 \mathrm{~mL}$ of water. The mixture is then poured into a solution of 5.0 grams of Potassium iodide $(\mathrm{KI})$ dissolved in $10 \mathrm{~mL}$ of water. This is then added with $100 \mathrm{~mL}$. 
Citation: Marloie T. Menchavez., Jerico D. Catipay., Aileen S. Espra., Pedrito M. Castillo., 2018. Antibacterial Properties of Bambusa vulgaris (Bamboo) Leaves and Eryngium foetidum (Culantro) Leaves against Staphylococcus aureus and Escherichia coli bacteria. Journal of Medicinal Plant Research., 6(1): 6-13. DOI: 10.22587/gjmpr.2018.6.1.2

2. Dragendorff's Reagent

a. Solution $\mathrm{A}-0.85$ grams of Bismuth nitrate is dissolved in a mixture of $10 \mathrm{~mL}$ Acetic Acid and $40 \mathrm{~mL}$ of water.

b. Solution B -8 grams of Potassium iodide (KI) is dissolved in $20 \mathrm{~mL}$ of water.

c. Stock Solution- Solution A and B is mixed with equal parts. The resulting mixture was stored in a dark bottle for a long time at room temperature.

d. To prepare the Reagent - Mix $1 \mathrm{~mL}$ stock solution with $2 \mathrm{~mL}$ Acetic Acid and $10 \mathrm{~mL}$ water.

3. Preparation of 2 molar Hydrochloric acid $(\mathrm{HCl})-17 \mathrm{~mL}$ of concentrated Hydrochloric acid is added to enough distilled water to make $100 \mathrm{~mL}$ of solution.

\section{Alkaloid Analysis through Laboratory Test Tube Method}

20 grams of plant materials from the stock plant extract was taken and placed in an evaporating dish. This is then allowed to evaporate to syrupy consistency over a steam bath. $5 \mathrm{~mL}$ of 2 molar Hydrochloric acid is added and heated with stirring rod in 5 minutes and then cool. About 0.5 grams of Sodium chloride $(\mathrm{NaCl})$ is added then stirred and filtered. The residue was washed with enough 2 molar of Hydrochloric acid to bring the filtrate to a volume of about $5 \mathrm{~mL}$. $1 \mathrm{~mL}$ of the filtrate is taken and tested with 2 to 3 drops of Dragendorff's Reagent and another $1 \mathrm{~mL}$ of the filtrate is taken and tested with 2 to 3 drops of Mayer's Reagent. The test result will then be confirmed with the confirmatory test.

\section{Confirmatory Test}

The remaining $3 \mathrm{~mL}$ of the filtrate was added with $28 \%$ ammonia until the solution is alkaline to litmus. This test was done carefully because it may cause burns, and its vapors are extremely irritating. The alkaline solution was extracted 3 times with small portions of less than $10 \mathrm{~mL}$ chloroform. The lower chloroform extracts were also combined. The upper aqueous layer was reserved for quaternary base amine oxide test. The chloroform extracts were evaporated to dryness under the hood and over a steam bath. The residue was taken up with $5 \mathrm{~mL}$ of 2 molar Hydrochloric acid and stirred over a steam bath for 2 minutes and cooled. The filtrate was filtered and divided into 2 portions. The 1 portion of it was tested with Mayer's reagent and the other with Dragendorff's reagent. If the result was recorded as $(++)$. Positive result was indicated in the test, which means, secondary alkaloid is present in the plant extract.

\section{Test for Quaternary Bases and Amine Oxide}

The alkaline aqueous layer was acidified with 2 molar of Hydrochloric acid. The filtrates were then filtered and divided into 2 portions. The first portion was tested with Mayer's reagent and the other with Dragendorff's reagent. If the result was indicated as (+), that means negative for quaternary bases or it may suggest that the extraction of the plant extract is incomplete.

\section{Testing for Steroids}

This test was done to determine the 2-deoxysugars and the unsaturated steroids through Keller-Killiani Test and LiebermannBurchard Test respectively.

1. Preparation of Keller-Killiani Reagents

a. Iron (III) Chloride Reagent $-3 \mathrm{~mL}$ of $1 \%$ Iron (III) chloride $\left(\mathrm{FeCl}_{3}\right)$ is dissolved in $50 \mathrm{~mL}$ glacial acetic acid.

b. $1 \%$ Iron (III) Chloride solution -1.0 grams of Iron (III) chloride $\left(\mathrm{FeCl}_{3}\right)$ is dissolved in $100 \mathrm{~mL}$ water.

2. Test Procedure - The one portion of the defatted aqueous layer free from hexane is added with $3 \mathrm{~mL}$ of Ferric chloride and then stirred. The $1 \mathrm{~mL}$ concentrated Sulfuric acid $\left(\mathrm{H}_{2} \mathrm{SO}_{4}\right)$ is added continuously to the test tube in an inclined position from a pipette, letting the acid trickle down along the insides of the test tube. The mixture is then allowed to stand upright and was observed for any coloration at the interface of the acid and the aqueous layer.

If the reddish-brown color that turns purple was observed. This result will be indicated as (+), which means 2-deoxysugar is present in the plant extract.

\section{The Liebermann-Burchard Test for Unsaturated Steroids}

A portion of the defatted aqueous layer free from hexane was added with $10 \mathrm{~mL}$ of dichloromethane, stirred with a glass rod for a few minutes and allowed to stand. The lower dichloromethane extract were pipetted off. The dichloromethane extract was dried by passing the extract through 100mg anhydrous sodium sulfate that is placed over dry filter paper in a funnel. The filtrate was divided into two portions which is the other one is used as control. The other portion was treated with 3 drops of acetic anhydride. This is done carefully because it is very corrosive. This is then treated with one drop of concentrated Sulfuric acid $\left(\mathrm{H}_{2} \mathrm{SO}_{4}\right)$. It is then observed for immediate color change. The portion was allowed to stand for an hour and observed for further color changes. The change of color is then compared to the control. The change of color that is brownish-green was not observed. If this result was indicated (-), that means, the unsaturated steroid is present in the plant extract.

\section{Test for Leucoanthocyanins}

The method used to test the flavonoids is the Bate-Smith and Metcalf Method. 10 grams of plant material from the stock plant extract is taken and allowed to evaporate to incipient dryness over water bath. This is then cooled in room temperature. Defatting is done by taking up the residue with $9 \mathrm{~mL}$ hexane and water, in 2:1 ratio by volume. The hexane extract is then discarded. The defatted aqueous layer is then defatted with $10 \mathrm{~mL}$ of $80 \%$ ethyl alcohol. The filtrate was filtered and divided into 
Citation: Marloie T. Menchavez., Jerico D. Catipay., Aileen S. Espra., Pedrito M. Castillo., 2018. Antibacterial Properties of Bambusa vulgaris (Bamboo) Leaves and Eryngium foetidum (Culantro) Leaves against Staphylococcus aureus and Escherichia coli bacteria. Journal of Medicinal Plant Research., 6(1): 6-13. DOI: 10.22587/gjmpr.2018.6.1.2

2 test tubes. The other portion is taken as control. The other portion is then treated with $0.5 \mathrm{~mL}$ concentrated Hydrochloric acid. Color is then observed if there's a change. The treated portion is then warmed for 15 minutes in a water bath. It is then observed if color is changed within an hour; the color is then compared with the control. If the result of this test was marked (+), that means there is a presence of Leucoanthocyanins.

\section{Test for Saponins}

The froth test is used to determine if Saponins are present in a plant extract. A volume of plant extract equivalent to 2 grams" plant material is taken and transferred to a test tube. $1 \mathrm{~mL}$ "gogo" extract in a separate test tube is prepared as the standard. $10 \mathrm{~mL}$ of distilled water to each of the test tube is added, stopper and shook both test tubes vigorously in 30 seconds. The test tube is allowed to stand for 10 minutes and was observed for "honeycomb" froth. The result of the plant extract was compared with that of the standard. If the result of this test was marked (+), that means saponins is present in the plant extract.

\section{Test for Tannins}

Ferric Chloride Test is used to determine if the extract have tannins. The reagents prepared are the following: $10 \%$ of Sodium chloride by dissolving 10 grams of Sodium chloride in enough distilled water to make $100 \mathrm{~mL}$ solution, Iron (III) chloride reagent by dissolving $3 \mathrm{~mL}$ of $1 \%$ of $\mathrm{FeCl}_{3}$ solution in $100 \mathrm{~mL}$ distilled water, and $1 \%$ solution of $\mathrm{FeCl}_{3}$ by dissolving 1 gram of $\mathrm{FeCl}_{3}$ in $100 \mathrm{~mL}$ distilled water. An equivalent of 10 grams of plant material from the stock plant extract is taken and allowed to evaporate to incipient dryness over steam bath. The residue is then extracted with $20 \mathrm{~mL}$ of hot distilled water and added with 5 drops of $10 \%$ Sodium chloride solution. The filtrate is then filtered and divided into 3 test tubes. One portion is taken as the control. An aqueous solution of tannic acid is used as reference standard. One portion of the filtrate was treated with 3 drops of $\mathrm{FeCl}_{3}$ reagent and also done the same to the tannic acid solution. The result was then compared to the control and the reference standard. If none of the color indications is observed to the extract that means no tannins present in the extract.

\section{Antimicrobial Test}

Preparation of the Plant Extract

The test material was prepared free from extracting solvent in which plant extract are completely syrupy in consistency. Water soluble extract are dissolved in normal saline solution. Normal saline solution is prepared by dissolving 0.85 grams of A.R. Sodium chloride in $1000 \mathrm{ml}$. distilled water.

Test Organisms

Staphylococcus aureus (gram-positive bacteria) and Escherichia coli (gram-negative bacteria) was used as assay organisms. These bacteria represent major group of microbial flora.

Preparation of the test organism or inoculum

For gram-positive and gram-negative bacteria, $0.5 \mathrm{Mc}$ Farland standards was used. A 0.5 McFarland was used to adjust the turbidity of inoculum prior to the cotton swabbing of the agar plates for the antimicrobial assays. The standard was prepared and subjected to quality prior to use. This standard contains approximately $1.5 \times 10^{8} \mathrm{CFU} / \mathrm{ml}$ of the test organism.

1. Preparation of $0.5 \mathrm{McFarland}$ Standard - $0.5 \mathrm{ml}$ of 0.048 molar of $\mathrm{BaCl}_{2} 2 \mathrm{H}_{2} \mathrm{O}$ to $99.5 \mathrm{ml}$ of 0.36 normality of Sulfuric acid $\left(\mathrm{H}_{2} \mathrm{SO}_{4}\right)$ THAT IS $1 \%$ volume per. $5 \mathrm{ml}$ was distributed into screw-cap tubes of the same dimension as those to be used in preparing the culture suspension. These tubes were tightly sealed and stored in the dark at room temperature. The turbidity standard was shaking vigorously on a mechanical vortex prior to use.

\section{Preparation of the Nutrient Broth for Gram-Positive Bacteria or Gram-Negative Bacteria}

The $1000 \mathrm{ml}$ nutrient solution was prepared. A loop of bacteria from the culture slant was inoculated in $50 \mathrm{ml}$ nutrient broth. The bacteria were incubated to the culture broth for 18 to 24 hours at $35^{\circ} \mathrm{C}$. The level of turbidity was observed which signifies that there is microbial growth.

Adjusting the turbidity

Five (5) $\mathrm{ml}$ of the culture broth was aseptically transferred to sterile screw-capped tubes. The bacterial suspension was the agitated on a vortex mixer and immediately compared against the prepared $0.5 \mathrm{ml}$ Mc Farland standard.

Preparation of the plates

Two plates were prepared for the Staphylococcus aureus and Escherichia coli. Approximately 15 ml melted nutrient agar was poured into the dry and sterile petri dishes. The medium was allowed to solidify. A sterile cotton swab was moistened into the test organism suspension. This was done through a wooden applicator handles. The sterile cotton swab was dipped into a suspension of the test organism. The moistened swab was then pressed and rotated firmly against the inside side wall of the tube just above the fluid level to remove the excess liquid.

Cotton Swabbing

The test organism was swabbed aseptically into a solidified nutrient agar by streaking the swab over the entire surface of the agar plate 3 times. The plate was rotated $60^{\circ}$ after each application to ensure an even distribution of the inoculum on the surface of the medium. The swabbed plates were allowed to stand for about 5 minutes before the paper disc with the plant extract was applied.

Application of the plant extract through Paper Disc Diffusion Method

One paper disc was picked using forceps to immerse it into the plant extract. The disc was then placed gently on the agar plate. The disc was then gently tapped, this is to ensure that the disc have a full contact with the agar medium. The plate was then incubated in 48 hours.

Reading the Assay Plate 
Citation: Marloie T. Menchavez., Jerico D. Catipay., Aileen S. Espra., Pedrito M. Castillo., 2018. Antibacterial Properties of Bambusa vulgaris (Bamboo) Leaves and Eryngium foetidum (Culantro) Leaves against Staphylococcus aureus and Escherichia coli bacteria. Journal of Medicinal Plant Research., 6(1): 6-13. DOI: 10.22587/gjmpr.2018.6.1.2

The clearing around the paper disc was then observed. This clearing around the paper disc is known as the zone of inhibition. The plates were the inverted and the diameter of each inhibition zone was then measured in millimeters. The result was expressed in ( $\mathrm{mm})$ and then recorded.

Bases of Analyzing the Antimicrobial Results

The analysis of the activity of the plant extract to the growth of bacteria was determined. Based on the standards, if the clearing or "halo" around the paper disc measured lesser than $10 \mathrm{~mm}(<10 \mathrm{~mm})$ is expressed as inactive, $10 \mathrm{~mm}$ to $13 \mathrm{~mm}$ inhibition zone is partially active, $14 \mathrm{~mm}$ to $19 \mathrm{~mm}$ inhibition zone is active and greater than $19 \mathrm{~mm}(>19 \mathrm{~mm})$ is considered very active (Guevara, 2005).

\section{Phytochemical Analysis}

\section{RESULTS AND DISCUSSION}

The phytochemical screening results of the ethanol extracts of B. vulgaris and E. foetidum are summarized in Table 1. Phytochemical analysis for Bambusa vulgaris identified the presence of tertiary alkaloids, quaternary bases, amines, unsaturated steroids, and saponins. On the contrary, Eryngium foetidum (culantro) leaves were observed to have the following phytochemicals, namely primary alkaloids, quaternary bases, amines, 2 deoxysugars, unsaturated steroids, and tannins. Also, 2-deoxysugars was only present in B. vulgaris extract, while saponins was only identified in E. foetidum extract. However, leucoanthocyanins was not found in both ethanol extracts.

The findings from a previous study conducted by Owolabi and Lajibe (2015), showed that chloroform, n-hexane and ethyl acetate extracts from $B$. vulgaris contain alkaloids, terpenoids, flavonoids, and tannins, however phenols was absent in both chloroform and n-hexane extracts, but was present in ethyl acetate extract. Additionally, preliminary phytochemical screening on the aqueous extract of $B$. vulgaris discovered the presence of alkaloids, flavonoids, saponins, terpenoids, steroids, coumarins, phytosterols, and protein (Joselin et al., 2014). Besides, a review study instigated by Paul et al. (2011), stated that chemical evaluation on $E$. foetidum leaves revealed the presence of flavonoids, saponins, tannins, and several triterpenoids. The absence of other phytochemicals was possibly affected by the organic solvent used in the test, owing to the fact that different organic solvents have distinctive capabilities in extracting biochemical constituents from a sample (Iwalokun et al., 2007). Furthermore, several studies highlighted the antibacterial properties of alkaloids against gram-positive and gram-negative bacteria (Cushnie et al., 2014), including S. aureus and P. aeruginosa (Mabhiza et al., 2016). Various reports have also shown that some alkaloids increase the antibacterial activity of antibiotics (Zuo et al., 2011; Mitchell et al., 2012; Lavigne et al., 2010; Marquez et al., 2005; Maurya et al., 2013) as cited by (Cushnie et al., 2014). Also, saponins extracted from Sorghum Bicolor L. Moench have been reported to exhibit antibacterial activity against $S$. aureus bacteria in 50 and $25 \mathrm{mg} / \mathrm{ml}$ concentrations (Soetan et al., 2006). Overall, the result denotes that B. vulgaris and E. foetidum contain phytochemicals that exhibit antibacterial properties against numerous pathogens.

Table 1: Phytochemical constituents present in the ethanol extracts of B. vulgaris and E. foetidum.

\begin{tabular}{|c|c|c|c|}
\hline \multicolumn{2}{|c|}{ PHYTOCHEMICALS } & \multirow{2}{*}{$\begin{array}{c}\text { Bambusa vulgaris } \\
+++\end{array}$} & \multirow{2}{*}{$\begin{array}{c}\text { Eryngium foetidum } \\
+ \\
+\end{array}$} \\
\hline $\begin{array}{c}\text { Alkaloids } \\
(+) \text { primary alkaloid } \\
(++) \text { secondary alkaloid } \\
(+++) \text { tertiary alkaloid }\end{array}$ & & & \\
\hline Quaternary Bases and Amines & & + & + \\
\hline \multirow[t]{2}{*}{ Steroids } & 2-deoxysugars & - & + \\
\hline & Unsaturated steroids & + & + \\
\hline Flavonoids & Leucoanthocyanins & - & - \\
\hline Saponins & & + & - \\
\hline Tannins & & - & + \\
\hline $\begin{array}{l}(-)=\text { not present } \\
(+)=\text { present in small amount } \\
(++)=\text { present in moderate amount } \\
(+++)=\text { present in large amount }\end{array}$ & & & \\
\hline
\end{tabular}

\section{Antibacterial Test}

The antibacterial activity of B. vulgaris and E. foetidum was examined using paper disc diffusion method. The results of the antibacterial test on both extracts against $S$. aureus and E. coli bacteria are shown in Table 2. S. aureus and E. coli were found to be susceptible to the ethanol extracts of both samples. Result confirmed that the growth inhibition of the extract from the $B$. vulgaris (bamboo) leaves against $S$. aureus reached $26 \mathrm{~mm}$ on the first trial, $27 \mathrm{~mm}$ on the second and $26 \mathrm{~mm}$ on the third trial with an average of $26 \mathrm{~mm}$, whereas in inhibiting the growth of $E$. coli bacteria, it reached 20mm growth inhibition from trials 1 to 3 respectively. The extracts from the E. foetidum (culantro) leaves reached $22 \mathrm{~mm}$ on the first trial and $23 \mathrm{~mm}$ on the second and 
Citation: Marloie T. Menchavez., Jerico D. Catipay., Aileen S. Espra., Pedrito M. Castillo., 2018. Antibacterial Properties of Bambusa vulgaris (Bamboo) Leaves and Eryngium foetidum (Culantro) Leaves against Staphylococcus aureus and Escherichia coli bacteria. Journal of Medicinal Plant Research., 6(1): 6-13. DOI: 10.22587/gjmpr.2018.6.1.2

third trial with an average of $23 \mathrm{~mm}$ against $S$. aureus while in E. coli it reached $20 \mathrm{~mm}$ from first to second trial and $21 \mathrm{~mm}$ on the third trial with an average of $20 \mathrm{~mm}$.

Previous studies indicated that $B$. vulgaris has a wide scope of antibacterial activity. A research administered by Ambika and Rajagopal (2017) showed that the acetone extract of B. vulgaris shoots, exhibit antibacterial activity against five strains of bacteria, namely Klebsiella pneumonia, Staphylococcus epidermidis, Bacillus subtilis, Enterococcus faecalis, and Enterobacter aerogenes. Two studies have also discovered that the dichloromethane extract obtained from the skin of bamboo shoots could inhibit the bacterial growth of S. aureus (Tanaka et. al., 2011 and 2013). Likewise, n-hexane and ethyl acetate extracts of $B$. vulgaris were found to demonstrate antibacterial activity against gram-positive bacteria Bacillus cereus and S. aureus (Owolabi and Lajide, 2015). On the other hand, E. foetidum was also found to display strong inhibitive activity against gram-positive, gramnegative bacteria and fungus. Lingaraju et al., (2016) showed that the ethyl acetate extract of E. foetidum inhibited the growth of $P$. aeruginosa $(28 \mathrm{~mm})$ higher than that of the standard Gentamycin $(18 \mathrm{~mm})$; and exhibited a $25 \mathrm{~mm}, 17 \mathrm{~mm}, 20 \mathrm{~mm}, 18 \mathrm{~mm}$ inhibition against $S$. aureus, E. coli, B. subtilis, and C. albicans. Moreover, revealed that methanol, petroleum ether, aqueous and chloroform extracts of the same plant also exhibit antibacterial activity against some of the previously mentioned pathogens.

Table 2: Antibacterial activity of B. vulgaris and E. foetidum extracts using sterilized $6 \mathrm{~mm}$ paper disc diffusion method.

\begin{tabular}{|c|c|c|c|c|}
\hline \multirow{3}{*}{ Trial } & \multicolumn{4}{|c|}{ Zone of Inhibition ( $\mathrm{mm}$ ) } \\
\hline & \multicolumn{2}{|c|}{ Bambusa vulgaris } & \multicolumn{2}{|c|}{ Eryngium foetidum } \\
\hline & S. aureus & E. coli & S. aureus & E. coli \\
\hline 1 & $26 \mathrm{~mm}$ & $20 \mathrm{~mm}$ & $22 \mathrm{~mm}$ & $20 \mathrm{~mm}$ \\
\hline 2 & $27 \mathrm{~mm}$ & $20 \mathrm{~mm}$ & $23 \mathrm{~mm}$ & $20 \mathrm{~mm}$ \\
\hline 3 & $26 \mathrm{~mm}$ & $20 \mathrm{~mm}$ & $23 \mathrm{~mm}$ & $21 \mathrm{~mm}$ \\
\hline Average & $26 \mathrm{~mm}$ & $20 \mathrm{~mm}$ & $23 \mathrm{~mm}$ & $20 \mathrm{~mm}$ \\
\hline
\end{tabular}

Table 3 indicates the standard list in analyzing the result of antibacterial test. Based on the standards, if the clearing or "halo" around the paper disc measured lesser than $10 \mathrm{~mm}(<10 \mathrm{~mm})$ it is expressed as inactive, $10 \mathrm{~mm}$ to $13 \mathrm{~mm}$ inhibition zone is partially active, $14 \mathrm{~mm}$ to $19 \mathrm{~mm}$ inhibition zone is active and greater than $19 \mathrm{~mm}(>19 \mathrm{~mm})$ is considered very active (Guevara et. al., 2005). The average growth inhibition exhibited by B. vulgaris against S. aureus and E. coli bacteria is considered highly effective, and the extracts of E. foetidum also display the same level of activity on both strains of bacteria. The results implicate that $B$. vulgaris and E. foetidum could potentially be used as antibacterial agents.

Table 3: The standard list in determining the antibacterial activity of a sample.

\begin{tabular}{|c|c|}
\hline \multicolumn{2}{|c|}{ Analysis of Result } \\
\hline Level of activity & Zone of Inhibition (mm) \\
\hline Inactive & $<10 \mathrm{~mm}$ \\
\hline Partially Active & $10-13 \mathrm{~mm}$ \\
\hline Active & $14-19 \mathrm{~mm}$ \\
\hline Very Active & $>19 \mathrm{~mm}$ \\
\hline
\end{tabular}

\section{CONCLUSIONS}

The study employed an in vitro method of examining the antibacterial activity of the ethanol extracts from Bambusa vulgaris (Bamboo) leaves and Eryngium foetidum (Culantro) leaves. The researchers also identified the phytochemical constituents present on both plants' ethanol extracts, in which tertiary alkaloids, quaternary bases, amines, unsaturated steroids, and saponins were identified to be present in the extracts B. vulgaris, while E. foetidum ethanol extracts were examined to have following phytochemicals, namely primary alkaloids, quaternary bases, amines, 2 deoxysugars, unsaturated steroids, and tannins. Furthermore, the two samples exhibited prodigious antibacterial activity against the growth of Staphylococcus aureus and Escherichia coli bacteria. B. vulgaris exhibited an average growth inhibition of $26 \mathrm{~mm}$ against S. aureus and $20 \mathrm{~mm}$ on E. coli which are both categorized as highly active. In addition, E. foetidum reached an average of $23 \mathrm{~mm}$ and $20 \mathrm{~mm}$ on both aforesaid pathogens respectively. The results imply that these plants could potentially be used as antibacterial agents and on other medicinal applications. 
Citation: Marloie T. Menchavez., Jerico D. Catipay., Aileen S. Espra., Pedrito M. Castillo., 2018. Antibacterial Properties of Bambusa vulgaris (Bamboo) Leaves and Eryngium foetidum (Culantro) Leaves against Staphylococcus aureus and Escherichia coli bacteria. Journal of Medicinal Plant Research., 6(1): 6-13. DOI: 10.22587/gjmpr.2018.6.1.2

The researchers of the study have identified the main flaw of this investigation, which is the lack of identification into which of the following phytochemical constituents are accountable for the inhibitive activity of the two samples, though the result of the phytochemical screening was shown. Thus, the researchers would highly recommend conducting further analysis on the ethanol extracts of both plants and identify which of the isolates exhibit the identified antibacterial activity. In addition, the use of other organic solvents should also be employed for the purpose of determining the extent of B. vulgaris' and E. foetidum' therapeutic properties.

\section{ACKNOWLEDGEMENTS}

The authors would like to extend their utmost gratitude to the people who have made significant contributions in this work, most importantly, Jennifer J. Dejarme from the Department of Science and Technology, Caraga State University, Ampayon Campus, for sharing her expertise in conducting the laboratory tests and to the administration of University of Mindanao for supporting this study.

\section{REFERENCES}

Ambika, K and B, Rajagopal, 2017. In Vitro Antimicrobial and Antiproliferative Activity of Bambusa vulgaris. International Journal of Pharmaceutical and Pharmaceutical Research, 9: 10-22.

Aniszewski, T. 2007. Alkaloids: Secrets of Life. Elsevier, 1: 156-158.

Arabski, M., A., Wegierek-Ciuk, G., Czerwonka, A., Lankoff, and W. Kaca, 2012. Effects of Saponins against Clinical E. coli. Strains and Eukaryotic Cell Line. Journal of Biomedicine and Biotechnology, 1: 1-6.

Bachir raho, G. and B. Abouni., 2015. Escherichia coli and Staphylococcus aureus most common source of infection. Laboratory of Molecular Microbiology. FORMATEX, 2: 637-648.

Bandow, J. E., H., Brotz, L.I., Leichert, H., Labischinski, and M. Hecker, 2003. Proteomic approach to understanding antibiotic action. Antimicrob Agents Chemother, 47: 948-955.

Cushnie, T. and A. Lamb, 2005. Antimicrobial activity of flavonoids. International Journal of Antimicrobial Agents, 26: 343-356.

Cushnie, T., B., Cushnie, and A. Lamb, 2014. Alkaloids: An overview of their antibacterial, antibiotic-enhancing and antivirulence activities. International Journal of Antimicrobial Agents, 44: 377-386.

Department of Health (2013). Mortality. Retrieved from http://www.doh.gov.ph/mortality.

Durgesh, D., and P. Tumane, 2014. Antibacterial Activity of Bambusa bambose L. against Multiple Drug Resistant (MDR) Bacteria Isolated from Clinical Specimen. International Journal of Pharmaceutical Sciences Review and Research, 25: 215-218.

Goyal, A.K., S.K., Middha, and A. Sen, 2010. Evaluation of the DPPH radical scavenging activity, total phenols and antioxidant activities in Indian wild Bambusa vulgaris "Vittata" methanolic leaf extract. Journal of Natural Pharmaceuticals, 1: 140 .

Guevara, B.Q., 2005. A Guidebook to Plant Screening: Phytochemical and Biological. UST Publishing House, Revised edition: $23-50$.

Hogberg, L., A., Heddini, \& O., Cars, 2010. The global need for effective antibiotics: challenges and recent advances. Trend in pharmacological sciences, 31: 509-515.

Honeychurch, P., 1980. Caribbean wild plants and their uses. Letchworth Press: 70.

Iwalokun, B. A., U. A., Usen, A. A. Otunba, and D. K., Olukoya, 2007. Comparative phytochemical evaluation, antimicrobial and antioxidant properties of Pleurotus ostreatus. African Journal of Biotechnology, 6: 1732-1739.

Joselin, J., S., Jenitha, T. S. S., Brintha, S., Jeeva, S., Sukumaran, and S., Geetha, 2014. Phytochemical and FT-IR Spectral Analysis of Certain Bamboo Species of South India. Journal of Biodiversity, Bioprospecting and Development, 1: 1-9.

Klevens, R., M. Morrison, J., Nadle, S., Petit, K., Ray, S., Gershman, and L., Harrison, 2007. Invasive MethicillinResistant Staphylococcus Aureus Infections in the United States. JAMA, 298: 1763-1771.

Lavigne J.P., J.M., Brunel, and J. P., Chevalier, 2010. Squalamine, an original chemosensitizer to combat antibioticresistant Gram-negative bacteria. Journal of Antimicrob Chemother, 65: 799-801.

Lingaraju, D. P., M. S.,Sudarshana, C., Mahendra, and K., Poornachandra Rao, 2016. Phytochemical Screening and Antimicrobial Activity of Leaf Extracts of Eryngium foetidum L. (Apiaceae). Indo American Journal of Pharmaceutical Research, 6: 4339-4344.

Mabhiza, D., T., Chetemerere, and S., Mukanganyama, 2016. Antibacterial Properties of Alkaloid Extracts from Callistemon citrinus and Vernonia adoensis against Staphylococcus aureus and Pseudomonas aeruginosa. International Journal of Medicinal Chemistry, 7: 1-11

Madappa, T. (2017). Escherichia coli (E. coli) Infections. Retrieved from http://emedicine.medscape.com/article/217485overview.

Mahabir, K. (2001). Medicinal and edible plants used by East Indians of Trinidad and Tobago. Chackra Publishing. House. Trinidad and Tobago.

Marquez, B., L., Neuville, N.J., Moreau, J. P., Genet, A. F., Dos Santos, Cano de Andrade, M.C., et al., 2005. Multidrug resistance reversal agent from Jatropha elliptica. Phytochemistry, 66: 1804-1811. 
Citation: Marloie T. Menchavez., Jerico D. Catipay., Aileen S. Espra., Pedrito M. Castillo., 2018. Antibacterial Properties of Bambusa vulgaris (Bamboo) Leaves and Eryngium foetidum (Culantro) Leaves against Staphylococcus aureus and Escherichia coli bacteria. Journal of Medicinal Plant Research., 6(1): 6-13. DOI: 10.22587/gjmpr.2018.6.1.2

Maurya, A, G.R., Dwivedi, M. P., Darokar, and S. K., Srivastava, 2013. Antibacterial and synergy of clavine alkaloid lysergol and its derivatives against nalidixic acid-resistant Escherichia coli. Chem Biol Drug Des. 81:484-490.

Mitchell, G., M., Lafrance, S., Boulanger, D. L., Séguin, I., Guay, M., Gattuso, et al., 2012. Tomatidine acts in synergy with aminoglycoside antibiotics against multiresistant Staphylococcus aureus and prevents virulence gene expression. Journal of Antimicrob Chemother, 67: 559-568.

Okon, J., E., Edet, G., Esenowo, and N., Umoh, 2013. Phytochemical Screening, Analgesic and Anti-inflammatory Properties and Median Lethal Dose of Ethanol Leaf Extract of Wild Species of Eryngium foetidum L. on Albino Rats. International Journal of Modern Biology and Medicine, 3: 813-818.

Owolabi, M. S. and L., Lajide, 2015. Preliminary phytochemical screening and antimicrobial activity of crude extracts of Bambusa vulgaris Schrad. Ex J.C. Wendl. (Poaceae) from southwestern Nigeria. American Journal of Essential Oils and Natural Products, 3: 3-5.

Paul, J. H. A., C. E., Seaforth, and T., Tikasingh, 2011. Eryngium foetidum L.: A Review. Fitoterapia, 82: $302-308$.

Philippine Statistics Authority, 2016. Top ten causes of death, 2011 - 2013 (Factsheet). Retrieved from https://www.psa.gov.ph/content/top-ten-causes-death-2011-2013-factsheet.

Ramcharan, C., 1999. Culantro: A much utilized, little understood herb. [ebook] Perspectives on new crops and new uses, In: J. Janick (ed.): 506-509.

Sáenz, M. T., M. A., Fernández, and M. D., Garcia, 1998. Antiinflammatory and analgesic properties from leaves of Eryngium foetidum L. (Apiaceae). Phytotherapy Research, 11: 380-383.

Sahbuti, D., 2004. Bamboo as medicine. Institute for Traditional medicine, Portland Oregon, USA. Retrieved from http:www.itmonline.org/art/bamboo.htm (7of7)6/1/2552 22:20:12.

Scalbert, A., 1991. Antimicrobial properties of tannins. Phytochemistry, 30: 3875-3883.

Schröder, S., 2011. Bambusa Vulgaris. Guadua Bamboo. Retrieved from http://www.guaduabamboo.com/species/?tag=Bambusa+vulgaris.

Smith, K. F., M., Goldberg, S., Rosenthal, L., Carlson, J., Chen, C., Chen, and S., Ramachandran, 2014. Global Rise in Human Infectious Disease Outbreaks. Journal of the Royal Society Interface. doi: 10.1098/rsif.2014.095.

Soetan, K. O., M. A., Oyekunle, O. O., Aiyelaagbe, and M. A. Fafunso, 2006. Evaluation of the antimicrobial activity of saponins extract of Sorghum Bicolor L. Moench. African Journal of Biotechnology, 5: 2405-2407.

Tanaka, A., H. J., Kim, S., Oda, K., Shimizu, and P. Kondo, 2011. Antibacterial activity of moso bamboo shoot skin (Phyllostachys pubescens) against Staphylococcus aureus. J. Wood Science, 57: 542-544.

Tanaka, A., K., Shimizu, and R., Kondo, 2013. Antibacterial compounds from shoot skins of moso bamboo (Phyllostachys pubescens). Journal of Wood Science, 59: 155-159.

World Health Organization, 2017. Infectious diseases. Retrieved from http://www.who.int/topics/infectious_diseases/en/. Retrieved date: February 22, 2018.

World Health Organization, 2018. E. coli. Retrieved from http://www.who.int/mediacentre/factsheets/fs125/en/. Retrieved date: February 18, 2018.

World Health Organization, 2017. Infectious diseases. Retrieved from http://www.who.int/topics/infectious_diseases/en/. Retrieved date: February 18, 2018

Zhang, J., J., Gong, Y., Ding, B., Lu, X., Wu, \& Y., Zhang, 2010. Antibacterial activity of water-phase extracts from bamboo shavings against food spoilage microorganisms. African Journal of Biotechnology, 9: 7710-7717.

Zuo, G. Y., Y., Li, T., Wang, J., Han, G. C., Wang, Y. L., Zhang, et al., 2011. Synergistic antibacterial and antibiotic effects of bisbenzyl isoquinoline alkaloids on clinical isolates of methicillin-resistant Staphylococcus aureus (MRSA). Molecules, 16: 9819-9826. 